\title{
John Berger and His Deconstructive Ways of Telling Stories
}

\author{
Gülden Kazaz Çelik ${ }^{1}$ \\ ${ }^{1}$ Özyeğin University
}

\section{ARTICLE INFO}

Keywords:

deconstructive; pain;

real; storyteller; voice.

\begin{abstract}
John Peter Berger born in 1926, in England, led a long life with so many inspiring ideas and a vast array of works until his death in 2017 in Antony, France. Being a prolific writer, he has been tried to be defined by so many people around the world as an art historian and critic, painter and theorist as well as a feminist or a Marxist. However, the way he introduces himself is far beyond these qualifications: He evaluates himself as a storyteller recounting the real life stories full of pain and suffering. In doing so, his stories do not merely serve as a medium for telling what people undergo in their lives but also they suggest new interpretations and meanings. Berger's To The Wedding is such a story blending what is spoken in the story with what it leaves out unspoken, which ultimately manifests Berger's deconstructive approach to storytelling.
\end{abstract}

\section{Introduction: John Berger, a Deconstructionist}

John Peter Berger born in 1926 in London, England, led a long life with so many inspiring ideas and a vast array of works until his death in 2017 in Antony, France where he spent much of his life. Born and bred as an English man, he has been lionised as an essayist and cultural thinker as well as an artist and screenwriter over the years in the United Kingdom. By the early 1950s, Berger was widely recognised as an art critic working for the New Statesman and New Society and "[he was] an increasingly visible presence in Great Britain, mainly because of his work with independent television and later because of the programs he broadcast for the BBC, some of which, as videotapes, [became] standard fare for secondary students in schools throughout the United Kingdom" (McMahon, 1982). Over the years, his Ways of Seeing has successfully reached to people at every social status ranging from adults to children and motivated them to grapple with his ways of seeing life.

Through various perspectives, he has been acknowledged in accordance with so many different perceptions. Berger is, for instance, "an art historian, novelist, playwright, critic, teacher, painter" (Livingstone, 2017) as well as an influential "theorist" (Sperling, 2017). No matter how Berger has been defined through the eyes of others, the common sense among those is his Marxist self. That is to say, so many critics assent to his Marxist concerns and interests. For example, once Berger is referred as a man proud of being a Marxist (Levy, 2017) whereas another time he is defined as a life-long Marxist (Kellaway, 2016). It is 
obvious that Berger's Marxist inclinations have been brought up so many times through the eyes of others concurring with each other on Berger's Marxist interests. Sivanandan, for instance, declares that Berger is a genuine and "intrepid" Marxist (2017); Andrew Salomone trumpets Berger as a "self-proclaimed [Marxist] [having] strongly held anti-capitalist beliefs often came out in his actions as well as his works" (2017). Besides, Asokan and Sperling both agree on Berger's Marxist self because each clearly asserts that Berger "[is] explicitly Marxist in his views" (Asokan,2015) and "he [consistently stays] true to a line of Marxist humanism" (Sperling, 2017). However, although he does not deny such a fact, he seems to avoid defining himself solely through one of his qualifications. To this end, Berger tries to define himself against the label of a Marxist by explaining how he can be seen as a Marxist and not simultaneously at his conversation with Jeremy Isaacs, a Scottish producer of some of the British television programmes including BBC series "Face to Face" (2013). By evaluating the possibility of having two qualifications at the same time, Berger responds Isaacs' question posed to clarify whether he is still a Marxist or not in such a clear manner:

Well, it all depends how much you've read Marx and how much you've studied Marx because this label has been put on me for nearly fifty years and it really means two things [...] Those who say are you a Marxist [...] in the sense that I think they mean the term, I would say 'No'. I never was really but if somebody asks me who really studied Marx like I have then I would say 'Yes' [...] I was a Marxist and insofar my thinking hasn't profoundly changed about the world. I'm sure I still am.

As it has been clearly understood here, Berger is fully aware of the fact that he has been very frequently called as a Marxist for a long time; nonetheless, he is cautious about being labelled as one of his qualifications since that would be a limitation on his multiple personality formed as a consequence of his numerous ways of seeing the world. This might be the reason why Berger says "I'm still among other things a Marxist" (Sperling, 2017), when inquired. In line with this assessment, it could be suggested that Berger is both a Marxist and not; therefore, such a view can be considered as a determining factor for his deconstructionist approach which decenters all the other centers.

Through the eyes of others, it is noticeable that Berger's deconstructive stance rejects to be pinned down to one qualification. For instance, Asokan emphasizes Berger's deconstructive approach stating how he "finds all absolute judgments [...] futile" (2015) in an article whose title significantly implies deconstructionist assumptions, "The Many Faces of John Berger". In this article, Asokan highlights how Berger challenges the long-standing truths in a way Derrida did before: Like Derrida who is against all the binary oppositions predicated on generalisations and assumptions, Berger holds a similar approach inviting the reader "to see and know the world differently" (Gunaratnam and Bell, 2017). Accordingly, Berger is primarily lionised as a deconstructionist "eye-opener" (Asokan, 2015) especially when his groundbreaking BBC series and its book, Ways of Seeing is considered.

Even in one of the articles jointly written by Gunaratnam and Bell (2017), Berger's deconstructionist self is stressed in the title "How John Berger Changed our Way of Seeing Art" in a direct reference to the book. The article reminds the very beginning of the book proposing to have a different way of seeing not only the world, but also the art. To this end, the first sentence of the book stating that "[t]he relation between what we see and what we know is never settled" (Berger, 1972, p.7) is emphasized to make such a claim. In her article "How John Berger helped us to be feminist", Serena Smith (2016) agrees on the fact that 
Berger's Ways of Seeing is a radical book "both in style and content" belonged to a writer with deconstructive sights "[which] opens, reveals and reverses the given power relationships". She shares this observation as follows:

[Berger's] work, Ways of Seeing, revolutionized the way art was perceived...[Berger] simply encouraged us to open our eyes; bringing older works of art into the $20^{\text {th }}$ - and now $21^{\text {st }}$ century, pointing out what no other critic had considered noteworthy: the world had changed... Berger drew attention to all the new, different 'ways of seeing'; his words almost became a lens to look through.

Accepting the fact that the world has changed, Serena Smith highlights the importance of Berger's encouragement to his readers to have 'a new, different ways of seeing' by "[turning] a light on that which was previously in darkness" (Serena Smith, 2016). In this sense, both Gunaratnam and Bell as well as Serena Smith appear to be fully aware of the deconstructive side of Berger through his book Ways of Seeing.

This realization is indeed a prevailing sense among the others who come to terms with the idea that Berger has a deconstructive perception on life traced simultaneously in his art and works as well. To illustrate, Ali Smith (2015) notes in his article, "A Gift for John Berger" that Berger makes us see changes in time. Since being "an insister on open eyes", Ali Smith believes that, Berger "[has written] warningly about how much we are led to accept the total system of publicity images as we accept an element of climate" (Ali Smith, 2015). Similarly, Livingstone (2017) emphasizes how "Berger [intends to take] his readers beyond the visible, towards a closer understanding of the world as it really is- the one capitalism, patriarchy, and empire try to hide from [them]". Sivanandan (2017) also assents with Ali Smith and Livingstone while talking about how Berger gives "eyes to see with". In the same vein, Kellaway (2016) describes how Berger's deconstructive approach to life enables people "to rethink what they have thought they know" about art, history, politics, and the act of looking and as a result of such a mindset she claims that "[such a reevaluation] is what everything [Berger] ... asks us to do" (Kellaway, 2016).

No matter how he has been defined through the eyes of others, it is evident that Berger closely corresponds with all and none of these evaluations including his Marxist and feminist qualifications owing to his deconstructive attitude. That is, his deconstructionist approach prevents him from being one person and therefore labelling him by one of his qualifications. In this sense, attributing one specific characteristic supposedly defining him would be a misleading assessment of his personal interests and attachments. Accordingly, when looked at through different contexts through the eyes of others, Berger can be recognized by his numerous remarkable characteristics along with his Marxism and feminism. Despite being evaluated through so many qualifications such as his Marxist and feminist views as well as his identification as an art historian, novelist, playwright, critic, teacher, painter or a theorist, Berger simply defines himself as a storyteller. At the time of his conversation with Esler (2011), he courageously states that "[he feels] that [he is] a storyteller. That's all. That's all".

Berger makes a reference to his own passion for telling and writing stories in his essay "Self-portrait" published in Confabulations, the compilation of his essays, with these words:

What has prompted me to write over the years is the hunch that something needs to be told and that, if I don't try to tell it, it risks not being told (Berger, 2016, p. 1). 
Hence, Berger clearly demonstrates that the urge forcing him to write letters, poems, speeches, stories, books and eventually notes for about eighty years is due to his urgent need. Explaining such a need through his short essay "Self-Portrait", Berger explains what the act of writing means for him and how he eventually comes up with the sense that "[...] the activity of writing has been a vital one" since "it [helps him] to make a sense of things and to continue" (Berger, 2016, p.1). In his conversation with Silverblatt (2013), Berger confesses that writing enables him to make a sense of the world we have been thrown into. This approach can be a justification of his reason why he prefers writing and telling stories in lieu of painting in his career. In justification of this, he says:

[the] reason I stopped painting at the end of the 40s was what was happening in the world: the threat, above all the threat of nuclear war. This was before the Soviet Union had parity. This threat was so pressing, that painting pictures- that somebody would go hang up on the wall- seemed... [dismissive hand gestures]. But to write, urgently, in the press, anywhere, everywhere, seemed so necessary (Asokan, 2015).

The reason determining his preference of writing instead of painting is the meaninglessness of painting pictures and selling them for someone who would buy them to hang up in their room. This would mean to remain silent, which is unacceptable for him; he needs to tell stories to make people know about what is happening in the world. Hence, when being interviewed by Wachtel (1995), he expresses that "[it] [is] not such a shift [but rather] a development" in his career since he holds a belief that whatever he chooses is a more meaningful task to undertake. In other words, it implies that painting gets a kind of luxury in a world where there is too much pain waiting for being shared.

\section{Berger's Deconstructive Ways of Seeing and Saying in To The Wedding}

Among so many stories he has told over the years, To The Wedding is the one which clearly manifests the common characteristics of Berger's storytelling while deploying a deconstructive approach towards it. On the one hand, it plainly recounts a touching story of a young, naïve girl who "[has been contaminated] by the HIV" (Berger, 2009, p. 75) and could not accept her illness coming out in the time when she feels the happiest joys of love and life. On the other hand, what the story of Ninon explicitly tells throughout the whole story opens up new possibilities of interpretation of the unspoken. That is, the story going beyond what is within the text determined by the intentions of the author, Berger invites the reader to dig out its potential meanings and functions. As he clearly suggests at his conversation with Wachtel (1995), stories are not merely bound to the told; they, indeed, rely heavily more on the untold, its silences and absences. Taking this into account, Berger's deconstructive seeing and saying observed in the story of Ninon has corresponded with Derrida's criticism on binary opposition primarily between the presence and absence suggesting that one needs the other to exist, the criticism of logocentrism. In this sense, To The Wedding is the embodiment of Berger's deconstructive storytelling juxtaposing what the text says nearby what it leaves unsaid.

\subsection{What Berger's Stories Tell}

Berger's storytelling is comprised of three specific characteristics indicating Berger's personal traits each of which can be easily examined in To The Wedding. First and foremost, 
what Berger says in his fiction is deeply embedded in the experience of pain and suffering. Deeply concerned, Berger has made several remarks to reveal this anxiety. While being interviewed by Silverblatt (2013), for instance, Berger says that "[life] is full of pain". In a conversation with Wachtel (1995), he clearly states that whatever he writes is almost always related to the painful experiences of people. As he tells in an essay entitled "Where are we?" published within the collection of his other essays under the title of a book Hold Everything Dear, "[he] is writing about the pain in the world" (Berger, 2007, p. 41) in order to deal with this pain. In this sense, Berger conceives of writing as a kind of consolation for the world surrounded by sufferings of many people as he aired his views on the Meridian BBC World Services (2001). In line with this perception, Berger believes that he could soothe away the pain and suffering of people by telling and writing stories; otherwise, he feels there would be no way of putting up with this pain and continue living. Such a mindset seems to justify why he feels the need to tell the painful story of a lovely young girl contracted AIDS at the age of early twenties.

To The Wedding is the story accompanied not only by Ninon's, the protagonist's, pains but also by other characters' emotional sufferings. Her father, Jean Ferrero, for example, is so helpless that he has no idea about how (or whether) he can bear his daughter's cry: "Papa, can you hear me? I'm twenty-three and I'm going to die?" (Berger, 2009, p. 75). Ferrero is well aware of his daughter's possible pains and sufferings; he knows that she will inevitably undergo all the troubles day by day and her health will be deteriorating in a short while. While Ninon's father is in pain of her suffering, her mother, Zdena, does not feel very much different. She accuses herself of not being with her daughter enough because she believes if she had been with her, she would never have experienced any of these and therefore she would not be suffering from this disease now. However, what is done cannot be undone and her pain remains until her last breath.

Telling all the pains and sufferings of the story, Berger aims to reach as many people as possible to connect their pains with the suffering of real people afflicted with this disease and their surroundings. It is apparent that he finds a meaning and value in Ninon's life and thereby wanting to share it with the others as the epitome of their suffering (Wachtel, 1995). In the light of such a commitment, the second characteristic of Berger's storytelling gets noticeable: Berger's stories are nourished by facts. Berger passionately and patiently explains how he has created his stories out of real life experiences while having a conversation with Susan Sontag (2017). Unlike Sontag claiming that storytelling is the act of invention, imagination and lies, Berger asserts that it is the activity of revealing the truth. In such a sharp disagreement with Sontag, Berger explains that:

[the] story exists somewhere between fiction and truth [...] My personal experience of telling and writing stories I think it has to begin off as truth [...] It started inventing (after observing) in relation to the truth [...] Why would it be fiction? Because it exists everywhere and nowhere and it is that displacement of place and time which makes something fiction, it seems to me [...] (In other words,) [the] fiction is something which exists [...] which goes beyond the immediate time or the immediate place. That is exactly what makes it fiction or what we call fiction (Sontag, 1983).

Observed above, Berger formulates the core of storytelling in the relationship between fact and fiction; in other words, the story is neither a solid fact nor a complete invention to Berger, 
which is in tune with his own deconstructive stance. He explicitly states that each story starts with a part of reality which can only be acquired by observation, looking and seeing; thus, every story transfers real people and their experiences in one way or another. What makes a story fictive, instead, is the perception of time and place since the story 'goes beyond the immediate time and immediate place' and bring people together on the platform regardless of any specific time or place.

To The Wedding is a such real concern for Berger; he intentionally chooses to think and write on it among so many other issues. He feels that he has to write about it as there is a need which he thinks he can only meet through writing. He expresses such an urge to write in his conversation with Isaacs in this way:

I didn't say to myself but something said to me. There is a book that needs to be written about AIDS. A novel. Some kind of book [...] So, I began thinking about it [...] I had quite a number of friends who had AIDS [...] Then, strange relation between life and invention and then in fact my daughter-in-law discovered that she was positive and then I actually I asked myself whether I could go on writing this book but eventually I decided I could and would (2013).

It is so evident that Berger has already had the idea of not choosing the subjects but being chosen by them. As long as he finds a kind of meaning in the experiences of people, he feels he is obliged to write about it. It is certain that To The Wedding is such a story for him. After observing his own environment including some of his friends, he has exposed to the experience of his own daughter-in-law, which overlaps with the moment when the fiction based on invention through observation is surprisingly combined by the fact, reality.

The third characteristic of Berger's storytelling is closely related to the fact that his stories are real life stories full of pains and sufferings awaiting the most appropriate voice to tell their stories to the others. That is, it is not a coincidence that Berger meticulously chooses each story's voice in accordance with its story (Wachtel, 1995) since he believes finding the most proper voice for the story is much more challenging than finding the subject to tell (BBC, 2001). Thus, it is apparent that the voice has such a significant role in Berger's storytelling: On the one hand, it shows a specific part of reality full of pain and suffering; on the other, it decides and authorizes whose voice needs to be heard throughout the whole story.

Berger decides on a voice of a blind tamata seller, named by Tsobanakos, in To The Wedding. Depicting an old blind man selling tamata which "are appropriate objects for a blind man to sell for [he] can recognize one from another by touch" (Berger, 2009, p. 4) seems to be quite thought-provoking. At first, the reader may not trust on a story narrated by a blind man whose perception is limited due to his blindness compared to any other people who are able to see. Indeed, there is an element of doubt about that when Tsobanakos starts the story by saying that:

I remember most of what I hear, and listen all day but sometimes I do not know how to fit everything together. When this happens I cling to words or phrases which seem to ring true (Berger, 2009, p. 3).

As if confirming the reader's suspicion, Berger shares this possibility or risk at the very beginning of the book while defining the main voice of the book belonged to a man who 
seems incapable of articulating what is precisely happening around. Nonetheless, Berger intends to show how capable and competent he is for this task.

Berger seems to have no hesitations in choosing Tsobanakos as the right voice of the book since he persistently tries to prove this in the course of the whole story. The reader may have a sense that he is incompetent to process what is happening around due to his imperfect vision; however, Tsobanakos is a man who thinks "[voices], sounds, smells bring gifts to [his] eyes [...] [He listens or he inhales] and then [he watches] as in a dream" (Berger, 2009, p. 7). That is, all the sounds he has exposed to turn into the sights for him, which can be highly possible when the fact that he was not born blind (Berger, 2009, p. 5) is considered. This could also well explain how this blind narrator Tsobanakos strongly describes the places around such as the kitchen of Federico in such a detailed way:

The kitchen is not big and seems smaller because of a larger motorbike on its stand behind the front door which gives on to the street. The way the saucepans have been left on the stove shows that the cooking is done by a man. In his room, [...] there's no trace of a feminine touch. A room where a man lives without a woman, and a man and room are used to it (Berger, 2009, p. 11-12).

The blind narrator portrays the kitchen much better than anyone else who has a flawless sight; in other words, his way of seeing outweighs the average perception of a man who is able to see since he feels more than what he would see. He is able to decode the sights in a way to decipher that the way the saucepans left on the stove is the signifier of the fact that it is a man's job. Once the reader is exposed to such vivid descriptions, he starts to depend on this blind narrator as the main source of all the other voices of the book including his own.

There is no question about what else a capable and competent voice of the story could tell. He has a shifting vision formed primarily by the sounds and voices; he can even hear "a completely silent voice spoke" (Berger, 2009, p. 11). Thus, beyond any shadow of doubt that the blind narrator is the right voice of the story which enables other voices of the story to be heard as well. Still, why the voice of the blind narrator is the most dominant one in Ninon's story is open to question: Is not it possible to recount the same story from Ninon's ways of seeing? Why not transferring what is happening through Ninon? Bailat- Jones satisfactorily responds to these questions in this way:

[it] is within [Ninon's] tragedy that the Greek peddler's [Tsobanakos] voice becomes relevant to the story [...] Despite the fact that his voice is compelling and highly effective, no one else could tell her story with as much empathy as a man who was not always blind but is now condemned to a life of darkness and helplessness (2010).

As speculated here, the reason for which the main voice of the story is chosen as the blind narrator can certainly be due to his empathy towards Ninon; however, there should be more than that especially when considering the fact that the voice of each Berger's stories is chosen with utmost care and importance.

\subsection{What is left unsaid in Berger's To The Wedding: Sounds of the Sights}

It is apparent that Tsobanakos is the true voice of the story revealing a part of reality full of pains since the way he tells the story goes beyond what it merely says. As a result, he offers various possibilities for interpreting what the story does not say. In this sense, Berger 
tends to juxtapose the presence of the text with its absence in a way Derrida suggests the coexistence of the binary oppositions. That is, Berger holds the belief that as long as the text has something to say, it concurrently keeps its unspoken to be told. This is why Berger, similar to Derrida, feels that they need to 'coexist'. Deeply influenced by such a Derridean critique of binary oppositions, Berger tells the story of Ninon in To The Wedding where he offers so many of these binary oppositions as the alternating parts to each other.

The story of To The Wedding is, therefore, a carnival of binary oppositions through which Berger makes a claim that nothing has a fixed center or everything exists with its alternating parts. Among so many critiques of binary oppositions in line with Derridean views, it appears that the major criticism is heavily relied on the use of five senses each of which supplements each other. Out of these senses, the most dominant one is the sense of hearing in lieu of seeing which is closely related to the voice of the story whose perception is nourished by sounds rather than sights. In other words, although the act of seeing as well as other senses are still needed in order to tell the story, it is definite that seeing is no longer the sole source for it. In this sense, blindness of the narrator is not a lack for the story; on the contrary, it is its richness to produce more unspoken pertinent to the text. It seems that the main voice and narrator of the story, Tsobanakos assents to this idea stating that:

[blindness] is like the cinema, because its eyes are not either side of a nose but wherever the story demands (Berger, 2009, p. 32).

Hence, the blindness of the narrator does not offer a blurred vision or an imperfect sight to the story; instead, it provides a multidimensional perspective for the reader in a very similar way that the cinema supplies to its audience.

To offer such a multidimensional perspective over the story, the act of seeing is supported by other senses, especially by hearing in the course of the whole story. To illustrate, when the coach driver drives, he has a very poor visibility like Tsobanakos and he is unable to make out anything clearly. Thus, he has to slow down to move on (Berger, 2009, p. 139). Lowering the speed, he starts to have a stronger sense of hearing helping him to continue driving. This scene is depicted in the story as follows:

With the engine cut, the noise of the sleeping passengers sounds louder: snores, the bubbling of deep breaths, murmurs like those of an organ after the organist has stopped playing. Outside the coach, silence, a silence of feathers (Berger, 2009, p. 139).

As clearly portrayed, once the vision of someone is blurred, the sense of hearing takes it over and enables him to hear the sounds much more clearly. This explains why the driver is able to hear the sounds of the engine, the sleeping passengers and their snores, breathes and murmurs better. He even notices the sound of the silence in a surprisingly similar way of Tsobanakos' recognition of "a completely silent voice [spoken]" (Berger, 2009, p. 11).

Offering such a rich background in sounds, the story deals with so many distinctive voices through the whole story. For instance, the story starts with a voice determining the flow of the story: It is the voice of Ferrero whose coming is heard by the blind narrator Tsobanakos from his clothes squeaking and his motor screeching. What Ferrero utters first is a question asking for anything for his daughter who is not expecting to have a baby as Tsobanakos correctly guesses (Berger, 2009, p. 5). As a result of this first utterance, the reader is provided by further details such as who Ferrero is and why he is looking for a special 
gift for her daughter in a very melancholic mood. In Ninon's story, these first sounds of the book offers sufficient clues to the reader without any need for sights: With the help of these sounds, it is clear that Ferrero is a railwayman whose accent "[makes] [Tsobanakos] think that he [is] French or Italian [and he guesses] he [is] [his] age, perhaps a little older" (Berger, 2009 , p. 6) and he is in great pain because of his beloved daughter's, Ninon's, illness causing her to suffer from 'everywhere' and hence condemning her to death (Berger, 2009, p. 6). Accordingly, it can be inferred that the first sounds of the story set the stage for the rest of the story especially thanks to Tsobanakos who identifies his surrounding through sounds and thereby hearing as a way of seeing.

In line with Tsobanakos' assumption of the fact that "[voices], sounds, smells (altogether) bring gifts to [his] eyes" (Berger, 2009, p. 7), the story does not only offer voices and sounds but also builds on the sense of smelling in order to see and perceive the surroundings. Thus, the sense of smelling has a contributing effect on the perspective of the story transferred by Tsobanakos who recognizes his environment through smells as well as sounds. This could also justify the reason why the whole story is embedded in both odours and scents. For example, the reader is exposed to the stink of ammonia, damp hair, lacquer, and paste at the hairdresser (Berger, 2009, p. 68), and the smell of tar coming off the road (Berger, 2009, p. 85) while he is satisfied by the smell of newly baked bread which the woman driver of the first tram of the day and Zdena smell at the same time (Berger, 2009, p. 32). Through the whole story, the reader is accompanied by more different smells including "[the] faint acrid smell of wine" (Berger, 2009, p.,86) "[the] smell of the fire [hanging] everywhere" (Berger, 2009, p. 185) or the perfume of Ferrero's gift to Ninon, Saba whose fragrance does not stay long (Berger, 2009, p. 155). When all these odours and scents are considered, it seems apparent that they supplement the story by offering an alternative to the senses of seeing and hearing, which also encourages new possibilities in the senses of tasting and touching as ways of telling Ninon's story.

Compared to the other senses, the sense of tasting seems to fall behind. Nevertheless, it is also as significant as other senses to form a full picture of the story so as to grasp how Derridean critique of binary oppositions supplement each other to reveal more than what Berger's story says. It is evident that the act of eating means more than a basic necessity to survive (although it serves as it is for some of the characters of the story such as Tsobanakos, Ferrero, Zdena's taxi driver etc.). To illustrate, the way Ninon eats of Les Coussins de Lyon appears to be more than eating to survive. She passionately tells what eating a box of these chocolates means for her as follows:

[My] papa got off his bike and from his leather jacket he pulled out this box which had a ribbon around it. Inside were Les Coussins de Lyon [...] They were too small and the silver was sugar and the green was mint and the fabric was marzipan. When you bit into one, your teeth went through the skin of marzipan and found truffle chocolate. What I didn't eat that night when Papa came back from Grenoble, I took next day to school to share with Gyel and Jeanne and Annette, and we all agreed we'd only marry men who could promise us a constant supply of Les Coussins de Lyon (Berger, 2009, p. 85).

The taste of Les Coussins de Lyon, in this sense, signifies Ninon's naïve childhood dreams of having a husband like her father who never neglects to buy Les Coussins de Lyon to her. Thus, its taste seems to be the flavour of her childhood. If the taste of chocolate is an indicator of her childhood, it can be adumbrated that the taste of moules given to Ninon by the Mussel 
Man is the signal of her callow transition period from childhood to adulthood since it is the time when Ninon has experienced her first abrupt sexual intercourse.

Allotting a specific place to the sense of tasting, the whole story enables the reader to follow the growth of Ninon. Starting with her naïve childhood memory of tasting the chocolate and following it with her eating of the moules reminding her unexpected first love experience, the story elaborates on the sense of tasting through a long wedding scene. Through the end of the story, Ninon celebrates her beloved Gino, his real and pure love, by eating congratulating her adulthood. Such an act of eating does not solely seem to refer to a specific phase of her life, roughly staged in accordance with tasting of different meals and drinks. Therefore, it needs to serve for a different purpose especially when considering the fact that Ninon is not the only one who continuously tastes what is served at the wedding: "Everyone is eating and talking, joking and drinking" and "[e]veryone at the table in the orchard sits down to eat. With the meat they will drink the dark wine of Barolo" (Berger, 2009 , p. 185). With Ninon's service and Federico's, Gino's father, command, everybody is forced to eat more cake since Federico believes "it's the best [they]'ll taste in [their] lifetime" (Berger, 2009, p. 188). As if they had no other chance of eating or they were compensating what they felt lost, everyone gets frantic about eating. In the end, "[the] wedding guests are becoming a single animal who has fed well" (Berger, 2009, p. 186) and Ninon manages to satisfy her insatiable appetite as if she felt it would be unlikely to do it so in future. That is to say, the sense of tasting is presented to reveal what is tacitly said in the story, i.e. different periods in a young immature girl's life.

Lastly, the sense of touching is also of critical importance to the wholeness of the story in addition to the sense of tasting (as well as the other senses mentioned previously). Indeed, since the whole story is about Ninon and her terminal disease preventing her from touching and being touched, the sense of touching is already at the core of the story. This is continuously reminded to the reader by Ninon crying that: "Nothing can touch [her] any more" (Berger, 2009, p. 80). What she possesses including the freedom to touch has been taken away from her because she has been touched by someone whom she does not want to be touched at all. Thus, even though she is still able to touch and feel the coldness of the water or "[feel] a pattern of coolness where the lace holes of her stockings have let the water through" (Berger, 2009, p. 189), she mostly feels pain when something touches her like the air which hurts her whole body (Berger, 2009, p. 197).

In the most deconstructive fashion, the story compensates what Ninon lacks by touching with what Tsobanakos has and in doing so the story makes a Derridean criticism on binary opposition between the presence and absence. To clarify, the sense of touching signifies the absence in Ninon's life, whereas it implies the presence in Tsobanakos'.

Accordingly, the lack of touching makes Ninon die gradually while its presence becomes the proof of Tsobanakos' presence which allows the criticism of so many other binary oppositions throughout the story, especially the one among the senses. Having deployed all these in such a deconstructive way, Berger introduces a new way of telling a story which is not limited to one sense, perspective, voice or any omnipotent narrator.

\section{Conclusion}

Beyond all evaluations about his personality, Berger is simply a storyteller, as he asserts. Although this aspect of his self has not been paid sufficient attention, he is indeed a prolific storyteller but not a conventional one. Because of his deconstructive mindset avoiding any 
labelling which might have been put on him over the years, he is a storyteller presenting a new way of telling stories. According to this perception, a story first should be a medium to tell a slice of painful reality transferred by the voice closest to its pain and then it needs to open up new possibilities for various meanings. In the story of To The Wedding, whatever the story tells enables the unspoken Derridean criticism suggesting the idea that the sense of seeing does not always suffice to tell a story; instead, it needs other senses to provide multidimensional perspective to offer richer meanings enabling different readings of the unspoken as well as the spoken.

\section{References}

Asokan, R, (2015), "The Many Faces of John Berger", New Republic Online, <https://newrepublic.com/article/126679/many-faces-john-berger>, Accessed: 5 Jan. 2019.

Bailat-Jones, M, (2010), “John Berger: To The Wedding”, Michelle Bailat-Jones Website, <https://michellebailatjones.com/2010/11/17/john-berger-to-the-wedding/>, Accessed 5 Jan. 2019.

Berger, J, (2007), Hold Everything Dear: Dispatches on Survival and Resistance, Verso, London and NY.

Berger, J, (2008), Ways of Seeing, Penguin Classics, London.

Berger, J, (2009), To The Wedding, Bloomsbury, London.

Berger, J, (2016), Confabulations, Penguin Classics, London.

"Face to Face", John Berger Interviewed by Jeremy Isaacs, (2013), YouTube, < https://www.youtube.com/watch?v=VLwmv-1AZDg>, Accessed 2 Jan. 2019.

Gunaratnam, Y, and Bell, V, (2017), "How John Berger Changed our Way of Seeing Art", The Conversation Online, <http://theconversation.com/how-john-berger-changed-our-wayof-seeing-art-70831>, Accessed: 6 Jan. 2019.

H. McMahon, J, (1982), "Marxist Fictions: The Novels of John Berger", JSTOR, Vol. 23, No. 2, pp. 202-224.

Kellaway, K, (2016), “John Berger: 'If I'm a Storyteller it's because I listen'”, The Guardian Online, <https://www.theguardian.com/books/2016/oct/30/john-berger-at-90-interviewstoryteller>, Accessed: 2 Jan. 2019.

Livingstone, J, (2017), “Beyond John Berger's Ways of Seeing”, The New Republic Online, https://newrepublic.com/article/139615/beyond-john-bergers-ways-seeing, Accessed 5 Jan. 2019.

"John Berger", Interview by Meridian BBC World Service, (2016), Youtube, < https://www.youtube.com/watch?v=Nyd1V0gp37I>, Accessed 7 Jan. 2019.

"John Berger on Ways of Seeing, Being an Artist, and Marxism", John Berger Interviewed by Gavin Esler, (2017), Youtube, BBC Newsnight Archives, <https://www.youtube.com/watch?v=b5y7QRt2bws>, Accessed: 7 Jan. 2019.

"John Berger with Michael Silverblatt", (2013), Youtube, <https://www.youtube.com/watch?v=BLivFgw i-8>, Accessed: 7 Jan. 2019.

Salomone, A, (2017), "Celebrating John Berger, the Storyteller Who Taught us to See", Creators, Vice Online, <https://www.vice.com/en_us/article/jpvw9y/john-berger-obituary>, Accessed: 2 Jan. 2019. 
Levy, S, (2017), "The Ways John Berger saw", Socialist Worker: International Socialist Organization, 〈https://socialistworker.org/2017/01/12/the-ways-john-berger-saw〉, Accessed 2 Jan. 2019.

Smith, S, (2016), "How John Berger helped us to be feminists", The Tab Online, <https://thetab.com/uk/leeds/2017/01/03/ways-john-berger-taught-us-feminists-28384>, Accessed 6 Jan. 2019.

Smith, A, (2015), "A Gift for John Berger", The Statesman Online, $\langle$ https://www.newstatesman.com/culture/art-design/2015/10/gift-john-berger〉, Accessed: 7 Jan. 2019.

Sivanandan, A, (2017), "John Berger 1926-2017 Truth-sayer in an age of lies", Tribute: Race \& Class, Volume: 58, Issue: 4, pp. 3-4.

Sperling, J, (2017), "The Transcendental Face of Art”, Guernica Online, Arts \& Culture.

"To Tell a Story", John Berger Interviewed by Susan Sontag, (2017), Youtube, $<$ https://www.youtube.com/watch?v=MoHCR8nshe8>, Accessed 6. Jan. 2019.

"Writers and Company", John Berger Interviewed by Eleanor Wachtel, (2017), CBC Player, $\langle$ http://www.cbc.ca/player/play/846474819873 >, Accessed 7 Jan. 2019. 